\title{
ADMINISTRATIVE MANAGEMENT, ADMINISTRATIVE REGULATION AND THE JUDICIAL PROCESS
}

\section{Jotin Dickinson $\dagger$}

In discussing problems connected with what is called public administration and administrative law, confusion not infrequently results from a failure to understand at the outset what is meant by the term "administration". A distinguished authority ${ }^{1}$ has described administration as essentially the process of translating the general into the particular, and, as one phase of this process, the task of applying abstract policies, principles and rules to specific cases. From this point of view, all government classifies itself into two functions: first, the function of formulating policies, principles and rules, and, secondly, the function of applying them. The first of these two functions is, of course, primarily that of the legislature, although, within certain limits, the function of formulating rules and policies can never be completely divorced from the organ or agency which applies them.

Administration as the function of bringing government to bear upon particular people in specific situations is thus as broad as the entire activity of government outside of the legislature. It covers every point where government comes in direct contact with individuals. It covers even the action of the judicial courts, as is shown by the phrase "administration of justice", for the courts themselves are administrative agencies in the sense that through their decisions governmental rules and powers are brought home to particular individuals and applied to affect their persons and properties. At the opposite extreme, administration includes the activities of governmental offices in hiring, promoting and discharging employees. It includes the activity of government in negotiating and contracting with private persons for the purchase of supplies and the construction of public works. Again, the broad field of administration covers the supply by government of services to individuals ranging all the way from the service of recording some paper like a deed or a will, through the supply of public education and unemployment relief, to the sale of water and electricity. All these fields of administration present problems of organization, management, supervision, and audit, involving questions of efficiency, economy, fairness, and justice in the larger sense. They have to do with the operation of government as a going concern-as a

†A.B., I9I3, Johns Hopkins; A.M., I9I5, Ph.D., I919, Princeton University; LL.B., I92I, Harvard University; LL.D., I929, Tusculum College; LL.D., 1934, Dickinson College; Professor of Law, University of Pennsylvania and General Solicitor of the Pennsylvania Railroad Company.

I. Hon. Louis Brownlow. 
business, if you will-conducting certain activities for the public which private persons cannot, or which at a given time and place the legislature thinks they cannot, satisfactorily supply.

These business activities of government, employing and discharging, contracting, buying, selling, planning and carrying out construction work, budgeting and financing, constitute the aspect of administration in which it is synonymous with what we may call management. This phase of administration is so much to the forefront today that some students of administration are tempted to identify administration with management, and to define the administrative process as nothing but the technique of management. But if we pause and survey the field of administration as a whole it becomes apparent that there is another great department of it where the emphasis is in a quite different direction; I refer to the field of administrative regulation. The Interstate Commerce Commission, the Federal Trade Commission, the Communications Commission, are not primarily or to any considerable extent engaged in management or business activities; they construct no roads or buildings or dams, sell no commodities or services, distribute no funds, and yet from a certain point of view they are administrative agencies par excellence. This distinction between administrative management and administrative regulation therefore seems basic in any effort to understand the relation between the administrative process on the one hand and the judicial process on the other. Which administrative process do we mean when we draw the distinction between administrative and judicial, the process of administrative management or the process of administrative regulation?

Let us begin with the process of administrative regulation, the process which the Interstate Commerce Commission and the Federal Trade Commission represent; and let us recur to the fact, pointed out above, that courts themselves are administrative agencies. What is the relation of an administrative body like the Interstate Commerce Commission to the administrative bodies of a judicial character which we call courts? This question raises first of all the inquiry as to what functions the courts perform in the process of regulation, of bringing governmental policy home to individuals.

Ever since the emergence of constitutional government in the middle ages from the cruder and less differentiated forms of government which existed prior to that time, the courts have been the final and ultimate agency, the agency through which in the last resort, governmental commands are applied to those individuals who for one reason or another do not wish to submit without raising some question of right or justice. 
Before the rise of constitutional government, if an official charged with the duty of collecting the revenue decided that an individual owed taxes to the government, there was nothing to prevent his seizing as much of the individual's property as he saw fit, although the individual might with good reason protest that no taxes were due. There was nothing to prevent the government through its police officers from throwing an individual into prison for an alleged crime, although the individual might claim that he had never been guilty of the crime. The establishment and development of judicial procedure in the courts was the answer of an awakening sense of justice to the oppressiveness of such governmental action. Today, and for centuries, government cannot in this country, or in any country living under our AngloAmerican system of law, punish an individual by imprisonment or, save in a very few exceptional cases, ${ }^{2}$ seize his property, without submitting the validity of its action to a judicial procedure in which the affected individual is entitled to present his case and, if possible, show that the governmental action involved is not warranted by law. This is the bulwark which has been built up against such excesses of governmental power as were illustrated, for example, by the famous lettres de cachet in France, which were warrants issued by executive officials without application to a court, and under which, without opportunity for trial or defense, individuals could be subjected, often for purely personal differences, to long terms of imprisonment. ${ }^{3}$

In order to prevent what most of us still feel to be the injustice of such procedures, the courts, today as in the past, constitute the final link in the process of regulation, the ultimate point of contact between government and the individual. There are, however, and necessarily always have been, administrative stages in the regulatory process preliminary and preparatory to the action of the courts, and in these preliminary and preparatory stages large and significant changes have been occurring within the past generation. In order to understand those changes, it is necessary to go back and contrast the administrative stages of the regulatory process several generations ago with the typical organization of those stages today.

Seventy-five years ago when government determined that certain types of conduct were to be prohibited in the public interest as, for example, the practice of a bank making excessive loans to its officers or falsifying its accounts, the normal method was for the legislature to pass a statute branding the acts in question as criminal and providing a penalty by fine or imprisonment. In the enforcement of such

2. Lawton v. Steele, I52 U. S. I33 (1894).

3. Funck-Brentano, L'Ancien Regime (ige6) 305-349. 
a statiute the phases preliminary to court action were left in the hands of the prosecuting attorney. He was under a duty to discover, so far as he could, particular instances where the statute had been violated; to present such evidence of violations as he might be able to ascertain to a grand jury; and, if the grand jury returned an indictment, to conduct trial of the defendants in court and secure a conviction if he could convince a jury of their guilt. In other words, the enforcement of the regulatory statute followed the same course and was left in the hands of the same agencies as the enforcement of the general criminal law.

It is a commonplace that one of the outstanding developments of the last fifty years has been the enormous extension of governmental regulation into fields of human conduct of a kind not regulated before. With the entrance of government into this wider field of regulation, it soon became obvious that the earlier method of administration through the District Attorney and the common-law courts would be ineffective and impractical. In the first place, it seemed unfair and unwise, in the case of many of the regulations which were introduced, to rely for enforcement upon criminal sanctions. Something less drastic was desired. In the second place, it was obvious that no single agency like the District Attorney's office would be adequate to conduct the investigations needed to secure enforcement of the law in a large number of such complicated and more or less specialized fields. In the third place, because of the complex character of many of the problems with which the regulatory legislation sought to deal, it was apparent that wise and intelligent enforcement required so far as possible the development of agencies which would be technically expert in each special field. Out of all these considerations emerged the so-called "regulatory commission", the type of agency with which the term "administrative" is today especially associated.

The regulatory commission originated largely as an agency to take over and perform that phase of the enforcement of a given regulatory statute which is preparatory to its ultimate enforcement in the courts, and which, in the case of ordinary criminal law, is still performed by the District Attorney. Its work, in other words, was to maintain contact with the special industry or activity regulated, to make investigations, sift complaints, reach preliminary determinations as to instances in which a violation had occurred, and then prepare and submit these cases to the courts. The relative complexity of the issues with which such commissions had to deal, and the long and detailed investigation of facts which they were of necessity required to make before determining that a regulation had been violated, made it practically imperative for these agencies to conduct hearings, compel the 
attendance of witnesses and the production of books and papers, and hear arguments in substantially the same way that a court would have to do when the case was ultimately brought into court. After proceedings of this character had been conducted before the commission, it seemed a futile duplication of effort to require that the evidence which had been taken and sifted by the commission should be presented again in court. Accordingly, a change of great significance was effected in the procedure. It came to be the rule, embodied in practically all the statutes which have been passed in the last thirty-five years, that after a commission had taken testimony and reached a determination it should no longer be necessary for the commission to retry the case in court, but that, if the individual affected regarded his legal rights as violated by the determination, he might, before being compelled to obey, appeal to a court, which would examine the record of the proceedings before the commission for the purpose of determining whether there was legal ground for the commission's action. The court, if it found that there was no such ground, would then stay the operation of the commission's order.

Accordingly, the present situation is that where the enforcement of statutes is entrusted to an administrative body rather than to the District Attorney, the courts still occupy an important position and perform an important function in the process, but a position and a function much more restricted than under the earlier procedure. They are still, as always, a last resort to which the individual whose conduct is being regulated can appeal to support his rights under the law; but he must generally act on his own motion to obtain their assistance, and in doing so he is not ordinarily entitled to have the courts look behind the administrative agency's finding of facts, or to have relief unless that agency has incorrectly applied the law or has made findings which are arbitrary and unreasonable on the evidence.

When we speak today of the relation between the judicial process and the administrative process, what is perhaps most frequently understood is the extent to which the courts are entitled to review decisions of these regulatory administrative agencies, before those decisions can be enforced against the individuals to whom they are directed. In approaching the merits of this issue, it is essential to contrast the judicial method and the administrative method in so far as they apply to the task of regulation.

Broadly, three main characteristics may be laid down as marking the judicial process administered in the courts. In the first place, each side is permitted to introduce in support of its contentions evidence having rational probative force and not consisting of mere rumor and 
hearsay, and each side is permitted to cross-examine and object to evidence so offered by the other. Secondly, decision is rendered by reference to known and established principles and rules, of which each side is in a position, so far as possible, to have advance knowledge and to which reference can therefore be addressed in argument. Thirdly, the agency making the decision is supposed to act impartially in the sense that it is free to decide in favor of either side which makes out the better case on the basis of the facts and the established rules of decision, and is not under pressure or compulsion to decide in favor of one side irrespective of those facts and rules.

Each of these characteristics has become embodied in some special feature of the judicial process as we observe it in the law courts. The first characteristic is embodied in the so-called rules of evidence, which are designed to eliminate from consideration vague impressions and rumors which may be of a prejudicial character, and which it may be impossible to rebut or disprove in the way in which definite and specific facts can be disproved. The second characteristic is embodied in the requirement that decision must be in conformity with, or at least foreshadowed by, rules or principles of law which are found in the statute books, or in prior decisions where they can be discovered in advance by the parties and used as the basis of rational argument, pro and con, so that a party may not be defeated by some novel principle of decision invented for the occasion and for the special purpose of deciding against him. The third characteristic of impartiality is safeguarded by the organization of the courts as a separate and independent agency, not under the control of the other agencies of government upon whose acts they may be required to pass when questioned by individuals.

To a certain extent all three of these outstanding characteristics of the judicial process may be, and have actually been, carried over into the administrative process when the latter is employed for the regulation of private conduct, or, as we say "quasi-judicially", in the procedure of bodies like the Interstate Commerce Commission. While it is true that such a body is not bound by all the technical rules of evidence which were developed to apply to a jury-trial at common law, it is also true that a commission may not act on mere hearsay or rumor and that the right of both parties to introduce evidence and to crossexamine is carefully preserved. Similarly, such bodies in their decisions conform to the statutes, and to the interpretative rules and regulations which they themselves have laid down; and they are not permitted to disregard those rules arbitrarily in specific cases. With regard to independence the analogy is not so complete. In a rateproceeding before a commission, for example, the case against the 
railroad or utility company is very likely to be prepared and conducted by the commission's own staff, not by an independent officer like a district attorney before a court; and in consequence we often hear the charge that administrative justice has an element of unfairness in it because the same agency acts as both prosecutor and judge. To this it may be replied that in most instances the administrative agency is at least independent of the political departments of the government so that there is no danger that its processes will be perverted into instruments of political pressure or revenge, as in the case of those administrative courts and commissions of the Stuart period in England which created the distrust of administrative justice that lingers in much of our thinking still. Secondly, there is the additional safeguard that the courts in reviewing an administrative order will scrutinize the record for evidence of unfairness and will uphold the order only if it has a reasonable support in the evidence.

With these similarities and differences between the judicial process on the one hand and administrative justice on the other, is it possible to compare the two so as to express preference for the superior excellence of either? In what sense if at all is it possible to ask whether one might with advantage be substituted for the other?

What we have at the present time in those fields of regulation which are committed to administrative agencies is a combination or blending of administrative with judicial justice. Up to a certain stage every proceeding follows the administrative pattern; beyond that stage there is practically always the possibility of resort to the judicial process. There is room for controversy as to the specific point at which the line should be drawn in the case of this or that agency or this or that type of case; but a suggestion in the abstract that-one. process should give way to the other can only mean either that the administrative process should be abandoned for entire dependence on the courts, or that the participation of the courts in the process should be eliminated and the administrative process extended to the complete exclusion of the judicial. It is the latter suggestion which is apparently most frequently intended when the question is raised today. In weighing the wisdom of the suggestion there are four points to be kept in mind:

(I) In the first place, the fact that administrative justice follows the pattern of judicial justice so closely in the essentials of fair play with regard to the admission and exclusion of evidence, conformity to law and the like, is to be attributed in no inconsiderable measure to the fact that administrative tribunals, like the lower law courts, act under the eye of an appellate court vigilant to correct departures from those standards. The suggestion that such appellate supervision should be 
removed in the supposed interest of speed and efficiency raises at least a suspicion that the objective is to eliminate these safeguards of administrative justice which now surround it and to substitute something different and more summary or, to use a current expression, "streamlined".

(2) In the second place, this suspicion is strengthened by the fact that the suggestion is usually accompanied by the complaint that administrative tribunals should be more free than at present to give effect to what is called "policy" in their decisions. The merit of this contention depends in large part upon what is meant by "policy". In one sense, law courts and administrative tribunals alike are already applying "policy" every day. The courts in the course of their decisions are constantly at work moulding the precedents by slow degrees to such changes in circumstances and social view-points as they are convinced represent permanent changes in the national life. On the other hand, when some more sudden change is desired, legislation or constitutional amendment announces the new policy, and the courts and administrative tribunals give effect to it. Something more than this, however, is apparently suggested. What this can be is hard to understand, unless it is freedom of administrative bodies to alter at their own volition the policy of a statute, or to enlarge or restrict the statutory mandate from case to case in accordance with purely external consideration which would be viewed without favor by an impartial law court but which might be brought home to the administrative agency in a very practical way by the exertion of political pressure. This leads to the third consideration.

(3) At present, administrative regulation is largely committed to independent commissions which, not unlike the courts, occupy a position outside the purely political branches of government. In the case of most of these agencies, there has been no reason to suspect that they have done otherwise than attempt to apply the statutes entrusted to their administration with the full degree of impartiality consistent with the policy of the statute. There is no suspicion for example that the Interstate Commerce Commission has construed its mandate to enforce reasonable rates as a mandate to order lower rates where the evidence and the commission's principles of decision would not justify such an order. We are beginning, however, to hear expressions of discontent with this independence of administrative tribunals. The suggestion is advanced that they should be brought into closer connection with the day-to-day political policy of government. No doubt the idea would be repudiated that this means that administrative tribunals should decide otherwise than on the evidence and in the light of the policy laid down 
by Congress; but how it can mean anything else, it is difficult to perceive. Administrative justice arranged to apply and enforce the shifting political considerations which motivate the day-to-day moves of the political branches of government would no doubt run afoul of judicial review as it now exists; but administrative justice of that character would also be something different from what we know today, and would amount to a return to what Lord Bacon had in mind when he suggested that in the interest of "policy" the King should control the decisions of the Chancellor. The elimination of that kind of administrative justice was one of the major steps toward free government of the type to which in this country we have always been accustomed.

(4) Finally, it is suggested that the task and purpose of administrative regulation have radically altered in the last few years. It has hitherto been generally supposed that the object of administrative regulation was to police certain types of activity and certain kinds of businesses by requiring them to conform to standards of conduct laid down by legislation. This was the theory upon which administrative regulation was introduced, and upon which its extension has usually been advocated. Recently a different theory has been suggested by some students and commentators. This new theory is that the purpose of administrative regulation is not to police business conduct, but rather to direct the management of businesses and industries. In other words, the function of the administrative body is no longer viewed as that of requiring from all the units subject to it a general conformity to certain uniform standards of behavior applicable to all, and stable in their application until changed for all. Such a body is rather, thought to perform the very different function of issuing orders and directions to this or that unit of an industry at this or that particular time, which in the judgment of the agency seem best adapted to promote the effectiveness of the industry. On this latter view it might well follow that the standards which the administrative body saw fit to enforce against one unit of an industry would be quite different from those which it was enforcing at the same time against another unit or units; and in the same way the standards which it enforces today might differ from those which it would enforce tomorrow, depending upon its judgment at the time as to the most effective way of accomplishing the ends which it had in view. ${ }^{4}$

4. This seems to be suggested, if not intended, in the following language of $\mathrm{Mr}$. Justice Frankfurter's majority opinion in Phelps Dodge Corporation $v$. National Labor Relations Board, 85 Sup. Ct. 753, 76r (I94I).

"The Act does not create rights for individuals which must be vindicated according to a rigid scheme of remedies. It entrusts to an expert agency the maintenance and promotion of industrial peace." 
With this suggested alteration in the character and direction of administrative regulation, we find ourselves back again in the presence of the other phase of administration which was noted at the outset, namely, administrative management. The suggestion in effect proposes to convert administrative regulation into administrative management, or rather to substitute governmental management for governmental regulation. While hitherto the development of administrative regulation has been largely towards assimilating it to judicial justice, surrounded by many of the safeguards of the judicial process, the new suggestion is to translate it into something like governmental operation, or, by way of example, to convert the Interstate Commerce Commission or the Bituminous Coal Commission into an agency not unlike the Tennessee Valley Authority. The question therefore presents itself as to the relation between administrative management and the judicial process.

The essence of the judicial process is the application of rules, principles and standards primarily for the purpose of delimiting the permissible sphere of activity of some individuals in the interest of others. The objective of management is different. It is not the protection of individuals, but the success of an enterprise, and often the success of an enterprise involves the sacrifice of individuals. Successful operation being the objective, the watchword of management is not uniform standards, equality of treatment, painstaking and impartial investigation of individual claims, but rather emphasis on quick decisions and sharp reversals of policy which may at one time favor certain individuals, and then, without warning, disadvantage them for no fault of their own.

Obviously government like every other human enterprise cannot function without management, but hitherto the most fruitful field in which to study the characteristics of management has been the field of private enterprise. One of the most outstanding of those characteristics has generally been impatience of rule, regulation and law. No lawyer who has ever had business men for clients, and no well informed person who reads the newspapers, can fail to be aware of the way in which management feels itself cramped and bridled by the restrictions of law which it regards as hampering its freedom and interfering with its efficiency. Given these characteristics of management and the manager, what are we to say of a proposal to substitute governmental management for governmental regulation?

In the field of private enterprise, it has frequently been the exuberance of management and its insistence on efficiency with resulting disregard of the individual which have led to the enactment of regulatory laws. For example, the successful management and operation of the 
Standard Oil Company was largely responsible for the enactment of both the Interstate Commerce Act and the Sherman Anti Trust Law. The success from their own standpoint of certain financial enterprises had a great deal to do with the enactment of the Public Utility Holding Company Act and the Securities Exchange Act. Law and regulation, in other words, in many of their modern forms are primarily designed to curb management rather than merely to prevent breaches of public order like the old-fashioned criminal law. This being so, in what sense can it be said that governmental management may be regarded as a possible substitute for regulation? In that case who would regulate the managers? Or would they remain unregulated?

The basis for the suggested substitution lies apparently in the fact that the management which is proposed as an agency of regulation is not private management, but governmental management in what is called the public interest. The question may, therefore, be raised as to whether public management in distinction from private is lacking in those characteristics which in the field of private management have been thought to require regulation. If there is a difference, the difference is embodied in the phrase "public interest". It is true that in the past there has apparently not been felt to be so much need for legal and judicial regulation of governmental management as of private enterprise. But it would appear that this has been largely due to the fact that until recently governmental enterprise has in the main concerned itself with such matters as the Army and the Navy where efficiency in the national defense has been thought largely to override considerations of private right. On the other hand, where government has taken over the operation of civil enterprises ranging from schools to water works, there has been the same tendency to subject management to legal control through the courts as in fields of private business. Pupils may enforce their rights to attend public schools ${ }^{5}$ and, where municipalities supply gas or water, they are subject to legal prohibitions against discrimination and unreasonable rates. ${ }^{6}$

Is such legal control rendered unnecessary and undesirable by the supposed management of government enterprises in the public interest? It may no doubt be urged by those who are impressed with the importance of efficiency and the desirability of relieving management from the hampering restrictions of regulatory law that in the case of govern-

5. School Trustees v. People, 87 I11. 303 (1877) ; Cross v. Walton Common School District, I2r Ky. 469, 89 S. W. 506 (1905); Commonwealth v. Altoona School District, $24 \mathrm{I}$ Pa. 224 (1913); Kidd v. Joint School District No. 2, I94 Wis. 353, 216 N. W. 499 (I927). 302-305.

6. Dickinson, Administrative Justice and the Supremacy of Law (ig27) 
mental enterprises the pursuit of the public interest eliminates the social desirability of regulatory rules. The difficulty with this argument is that public interest is a term which ultimately breaks down into a mere balancing of private interests. Suppose for example that government should manage the railroads. If the agency charged with the task should aim at the managerial goal of efficiency it would inevitably find itself in conflict, like private management, with the claims of shippers and communities. In the same way a government agency charged with the operation of the power industry would probably find itself in conflict with other government agencies managing the coal and oil industries. In such a situation, which is the public interest, the interest of coal, or the interest of power, or the interest of oil?

Only two devices have been discovered in human experience for resolving such conflicts. One is the judicial process, operating through law to weigh and balance the claims of individuals by appeal to principles and standards. The other is the absolute ruler, who might be described in modern terms as a "national general manager", free to "coordinate" by disregarding all separate claims of whatever character in the interest of momentary conceptions of governmental efficiency. The task of such a general manager might well have been supposed to exceed human capacity if it were not for the living examples which Europe at present affords us.

Into the comparative merits of absolute government and government through legal procedure, it is not of course worthwhile to enter. On that subject practically everything has long ago been said, and most of us have made up our minds one way or the other. For most of us the answer is written in the history of our own institutions. If we reach the conclusion that we need not merely management, which we are bound in any event to have, whether public or private, but also need law as a check on management, this does not mean that the courts must be resorted to as the sole agency of legal control. The courts are simply the ultimate agency, not the sole one. As pointed out above, there is much by way of enforcing the law which can be done and should be done within the administration itself. If the place of law in the management of government is accepted, then regard for law can be embodied, and needs to be embodied, within the operations of the administrative agencies themselves. If not embodied there, the insistence on administrative expertness and on standards of proper administrative procedure goes for naught. If, on the other hand, those standards are actually present in administration, then there is no need for administrators to object to their work being brought to the ultimate test of the judicial process as applied in the courts. 